International Journal of Islamic Educational Psychology

Vol. 2, No. 2, December 2021

DOI: https:// doi.org/10.18196/ijiep.v2i2.13145

\title{
An Investigation into the Self-Handicapping Behaviors in Terms of Academic Procrastination
}

\author{
${ }^{1}$ Muhammad Fadhli*, 2 Subhan Ajrin Sudirman, ${ }^{3}$ Hatice Kılınçer \\ ${ }^{1}$ Universitas Abdurrab Pekanbaru, Indonesia \\ ${ }^{2}$ Universitas Islam Negeri Imam Bonjol Padang, Indonesia \\ ${ }^{3}$ Bingöl University, Turkey
}

*Corresponding email: muhammad.fadhli@univrab.ac.id

ARTICLE INFO

Article History

Received : 17/11/2021

Revised : 08/12/2021

$23 / 12 / 2021$

Accepted: $23 / 12 / 2021$

Keywords

Investigation, Behavior,

Self-Handicapping,

Psychology, Academic

Procrastination
ABSTRACT

Academic procrastination in completing tasks often occurs in students. If left unchecked, it will affect emotional instability, attitudes, and daily behavior. One of the reasons behind it is the threat of self-esteem and self-image. Among the individual attitudes of emotional evasion and threatening self-esteem and self-image is selfhandicapping. This study aims to determine the relationship between self-handicapping and academic procrastination in UIN Imam Bonjol Padang students. The research instrument used a self-handicapping scale and an academic procrastination scale. Data were analyzed using the Pearson correlation analysis technique. The results showed a significant number of $0.234(\mathrm{p}>0.05)$, meaning no relationship between self-handicapping and academic procrastination in UIN Imam Bonjol Padang students.

This is an open access article under the CC BY-SA license.

\section{Citation:}

Fadhli, M., Sudirman, S. A. \& Idrus, F. (2021). An investigation into the self-handicapping behaviors in terms of academic procrastination. International Journal of Islamic Educational Psychology, 2(2), 191-202. DOI: https://doi.org/10.18196/ijiep.v2i2.13145 
Fadhli, Sudirman \& Kılınçer | An Investigation into the Self-Handicapping Behaviors in Terms of Academic Procrastination

\section{INTRODUCTION}

Higher education facilitates students in coaching and increasing student creativity, which aims to improve the quality of a nation. With a good system, both in concept and implementation, creativity, morals, and the ability to answer the challenges of the present and future times is expected. The educational process during college differs from the educational process during school. In higher education, the learning materials provided to students are more extensive and complex than the subject matter provided in high schools (Khaidir, \& Suud, 2020). An active learning process is more used as the right method in the learning process during college in college.

Dewey developed a concept of education called progressive education. Progressive education makes students the center of the learning process. Students must be more active and independent in learning (student-centered). While educators are passive, acting as facilitators will later control the learning process (Martin, 2018).

Progressive education aims to change education which is more dominated by lecturers, making students passive and affecting students to be less innovative and creative because of the tendency to accept the knowledge. Therefore, by giving students study assignments, active learning is expected to make these students active during education.

While in college, students will not be separated from assignments. Assignments have a time limit or deadline. Therefore, students must not waste time to complete them and meet the deadline (Willetts, 2017). Assignments represent learning because it is students' main activity; learning science, organizing, socializing, and being a leader. Students have several attributes, including a core group of youths, scholars or intellectuals, future leaders, and idealists because the nation's future is at stake. Willetts (2017) stated that one of the criteria for successful students is to manage the right time and have a time limit for each process.

Küchler et al. (2019) found that many students regretted wasting time. The tendency not to immediately start assignments indicates procrastination because it causes individuals to delay doing and completing assignments. This statement proves that every student does not possess the ability to manage time well. If bad timing habits continue students will create procrastination (Rouzi, et al., (2020). Sarirah dan Chaq (2019) mentioned that procrastination could delay a job and is considered task avoidance, caused by unwillingness to do the task and the fear of failing.

As a religion that regulates all aspects of life, Islam is concerned about the ummah's lives. Islam forbids its ummahs from procrastinating. Islam has previously studied the problem of procrastination, the effects and dangers of procrastination. As Allah SWT in Q.S Al-'Ashr verses, 1-3 said: By time. Indeed, 
Fadhli, Sudirman \& Kılınçer | An Investigation into the Self-Handicapping Behaviors in Terms of Academic Procrastination

mankind is in loss, except for those who have believed and done righteous deeds, advised each other to truth, and advised each other to patience.

Based on the arguments above, procrastination has penetrated almost all lines of human life, including education, called academic procrastination. Afzal dan Jami (2018) stated that academic procrastination often occurs in university. Schmidt et al. (2021) conducted a study of 291 American students and found that $40 \%$ of students procrastinated while completing their assignments. Suppose the habit of procrastinating is left too long. It will delay completing the final project.

Procrastinators have anxiety about being criticized or evaluated by others because they tend to protect and maintain their self-image. They are afraid that failure will erode other people's positive views and impressions. Therefore, procrastinators prefer to delay completing tasks (Korstange et al., 2019).

Kathleen dan Basaria (2021) suggested that procrastination occurs because of low self-esteem and high social anxiety. Procrastinators tend to experience performance failures. Therefore, procrastinators delay starting and completing a task because they are worried and reluctant if later criticized by others.

Schwinger et al. (2021) suggested that one way in a work situation to maintain self-esteem and self-image is to make attributions or assume that every performance done if successful is a factor of self-ability and if later failure in performance is due to interference from outside parties and not due to self-ability factors called self-handicapping. This opinion explains that the self tends to maintain self-esteem and self-image from aspects that can threaten it by actively looking for factors used as reasons for success or failure.

Kinık dan Odacı (2020) found a negative relationship between self-esteem and academic procrastination. The higher the self-esteem of a person, the lower the academic procrastination and the lower the self-esteem, the higher the academic procrastination. Therefore, if someone has high self-handicapping, it will cause someone to procrastinate. The lower a person's self-esteem, the higher the selfhandicapping used to protect his self-esteem.

Self-handicapping is related to attribution because individuals tend to cover up any mistakes made, not from a lack of self or performance. However, the difference is that self-handicapping is before the performance or activity (Karami et al., 2020). Individuals with high self-handicapping tend to avoid completing tasks because they always avoid evaluative situations and cannot manage time. The tasks and work are not completed properly (Y1ldırım \& Demir, 2020). Selfhandicapping protects and maintains self-esteem by making a series of attributions. The attribution made occurs before the performance, externalizing the failures and internalizing the successes.

The obligations will give people a strong mentality because obligations should not be abandoned following Allah SWT's words in the QS. At-Tahrim verse 6: O you who have believed, protect yourselves and your families from a Fire whose fuel is people and stones, over which are [appointed] angels, harsh and severe; 
Fadhli, Sudirman \& Kılınçer | An Investigation into the Self-Handicapping Behaviors in Terms of Academic Procrastination

they do not disobey Allah in what He commands them but do what they are commanded.

Suppose someone already knows their responsibilities and obligations. As Allah SWT mentioned in QS, they will complete every business, work properly, and benefit from completing all affairs. Taha verse 132: Enjoin prayer upon your family [and people] and be steadfast therein. We ask you not for provision; We provide for you, and the [best] outcome is for [those of] righteousness.

It is important to study procrastination, especially student academic procrastination. The researchers, in this case, conducted a study by looking at the relationship between self-handicapping and academic procrastination in students.

\section{METHODS}

The population of this study was 764 university students (male and female with an age range of 18-20 years). The sampling technique included simple random sampling with 446 students from five faculties at Universitas Islam Negeri Imam Bonjol Padang. The data used were obtained through a scale with a self-report format based on reports or statements and experiences and perceptions of research subjects. Self-report refers to Pavot (2007) stating that self-report is the right tool to express subjective thoughts. The data collection tools used in this study included the academic procrastination scale and the self-handicapping scale. The researchers developed a data collection tool based on expert opinion and focus group discussions on obtaining behavioral indicators and statement items more in line with actual conditions. The item scaling model in this study uses a Likert model scale in the form of a statement with several answer choices containing the level of conformity with the actual conditions of the respondents. A self-handicapping scale measured students' self-handicapping, based on the concept of Berglas and Jones (1978), while for the academic procrastination variable, the instrument was based on Solomon's (1984) theory.

\section{RESULT}

The hypothesis in this study is a positive correlation between self-handicapping and academic procrastination. The higher the level of self-handicapping, the higher the level of academic procrastination. The categorization of the level of self-handicapping shows that the empirical mean of self-handicapping students of the Department of Islamic Psychology, Faculty of Ushuluddin IAIN Imam Bonjol Padang is categorized based on the ideal mean with reasons to balance the subject divided into low, medium, high. The results can be seen in Table 1.

Table 1. Categorization based on Self-handicapping Scale

\begin{tabular}{|c|c|c|c|c|}
\hline No. & Score & Total & Category & Percentage \\
\hline 1 & $>66$ & 73 & High & $15,66 \%$ \\
\hline 2 & $49-65$ & 109 & Medium & $23,39 \%$ \\
\hline 3 & $<48$ & 284 & Low & $60,94 \%$ \\
\hline
\end{tabular}


Fadhli, Sudirman \& Kılınçer | An Investigation into the Self-Handicapping Behaviors in Terms of Academic Procrastination

Table 1 shows that of the 446 subjects studied, 284 or $60.94 \%$ have low selfhandicapping levels, 109 people or $23.39 \%$ have a medium level of selfhandicapping, and 73 people $15.66 \%$ have a high score. From the percentage of self-handicapping in the table, UIN Imam Bonjol Padang students dominantly have a low level of self-handicapping.

Meanwhile, the categorization of the level of academic procrastination of UIN Imam Bonjol Padang students is categorized based on the ideal mean because the subject is divided into three categories, namely low, medium, and high. The formulation of categorization into three internal categories. The results can be seen in Table 2.

Table 2. Categorization based on Academic Procrastination Scale

\begin{tabular}{|c|c|c|c|c|}
\hline No. & Score & Total & Category & Percentage \\
\hline 1 & $>133$ & 68 & High & $14,59 \%$ \\
\hline 2 & $96-132$ & 211 & Medium & $45,27 \%$ \\
\hline 3 & $<95$ & 187 & Low & $40,12 \%$ \\
\hline
\end{tabular}

Table 2 shows that of 466 subjects studied, 187 people or $40.12 \%$ have a low level of academic procrastination; 211 subjects or $45.27 \%$ have a moderate level of academic procrastination and 68 subjects or $14.59 \%$, have a high level. Thus, UIN Imam Bonjol Padang students are in the medium category.

The normality test in this study aims to determine whether the data population is normally distributed or not. The normal data distribution states that the research subject is representative or can represent the existing population. On the contrary, if the distribution is not normal, the subject is not representative or represents the population. The normality test in this study used the One-Sample Kolmogorov Smirnov test. The data was declared normally distributed if the significance was greater than 0.05 .

Table 3. Self-handicapping Scale Distribution Normality Test and Academic Procrastination

\begin{tabular}{ccl}
\hline Variable & Normality Test Results & Description \\
\hline Self-handicapping & 0.528 & Normal \\
Academic & 0,671 & Normal \\
Procrastination & & \\
\hline
\end{tabular}

Table 2 shows that of 466 subjects studied, 187 people or $40.12 \%$ have a low level of academic procrastination; 211 subjects or $45.27 \%$ have a moderate level of academic procrastination and 68 subjects or $14.59 \%$, have a high level. Thus, UIN Imam Bonjol Padang students are in the medium category.

The normality test in this study aims to determine whether the data population is normally distributed or not. The normal data distribution states that the research subject is representative or can represent the existing population. On the 
Fadhli, Sudirman \& Kılınçer | An Investigation into the Self-Handicapping Behaviors in Terms of Academic Procrastination

contrary, if the distribution is not normal, the subject is not representative or represents the population. The normality test in this study used the One-Sample Kolmogorov Smirnov test. The data was declared normally distributed if the significance was greater than 0.05 .

Table 4. Scale Distribution Linearity Test

\begin{tabular}{cc}
\hline Linearity Test Results & Description \\
\hline 0,049 & Linear \\
\hline
\end{tabular}

Table 4 shows the ANOVA output table that the significance value for linearity is 0.049 because the significance is small from $0.05(0.049<0.05)$. Thus, there is a linear relationship between the self-handicapping variables on academic procrastination. Then the assumption linearity is met.

Pearson correlation analysis was used to determine whether or not there was a relationship between self-handicapping and academic procrastination. The calculations can be seen in Table 5 .

Table 5. Pearson Correlation Analysis Results

\begin{tabular}{ccc}
\hline Variable & $\begin{array}{c}\text { Assumption Test } \\
\text { Results }\end{array}$ & Description \\
\hline $\begin{array}{c}\text { Self-handicapping } \\
\text { Academic Procrastination }\end{array}$ & 0,235 & Not Significant \\
\hline
\end{tabular}

Table 5 shows that the Pearson correlation value between the self-handicapping variable and academic procrastination is 0.235 ( $p>0.05)$, meaning that the significance level between the two variables shows no relationship between selfhandicapping and academic procrastination. Based on the correlation coefficient calculation with a coefficient of 0.235 , the value of the $r$ count is 0.235 while the $r$ table is 0.263 . The hypothesis is accepted if the $r$ count is greater than the $r$ table. On the other hand, if the $r$ count is smaller than the $r$ table, the hypothesis is rejected (Sugiyono, 2013). Thus, there is no relationship between selfhandicapping and academic procrastination in UIN Imam Bonjol Padang students.

\section{DISCUSSION}

Statistical analysis of research data is not in line with the hypothesis that has been described that self-handicapping can cause academic procrastination. People with high self-handicapping tend to avoid task completion because they always avoid situations that are evaluative, less able to manage time so that the tasks and work given are not completed properly.

Someone who does self-handicapping tends to look for various reasons that aim to protect self-esteem and self-image by reasoning that every failure is due to external factors that influence such as physical conditions, health complaints, 
unsupportive situations, following the characteristics of academic procrastination proposed by Balkis (2013) that a procrastinator tends to do academic procrastination is due to a tendency to delay work due to reasons including deliberately not starting work, which may be due to reasons for physical and psychological conditions and disturbances from outside such as being more inclined to do activities that they enjoy, and so on.

As explained in the previous discussion, self-handicapping consists of behavioral self-handicapping and self-reported self-handicapping (Barutçu Yıldırım \& Demir, 2020). Behavioral self-handicapping is a form of self-handicapping that directly observes behavior, and self-reported self-handicapping is a form of selfhandicapping that can be known through a statement given by someone. Due to several considerations such as limited time, effort, cost, and human resources in conducting behavioral self-handicapping research, in this study, the research is self-reported self-handicapping, namely self-handicapping, which can be measured through statements obtained through a self-handicapping scale.

Park and Brown (2014) concluded that self-reported self-handicapping does not have much effect on performance but rather serves to maintain self-image and self-image. Meanwhile, in this study, what is revealed is self-reported selfhandicapping and academic procrastination, which are essentially individual performances.

In this study, self-handicapping behavior did not contribute to academic procrastination protecting self-esteem. Following the opinion expressed by Solomon and Rothblum (1984) that there are three factors behind someone to do academic procrastination:

1. Fear of failure

Fear of failure is a feeling of guilt when not achieving something. Procrastinator tends to avoid the tasks assigned to them;

2. Aversive the task

Feelings of displeasure in assignments such as feeling the task load are too heavy, not liking the course so that it has an impact on displeasure and reluctance to work can cause someone to procrastinate;

3. Other factors

These factors include dependence on the help of others, excessive risk-taking that results in difficulty making decisions, less assertive attitude, boredom, fatigue, and difficulty concentrating.

Regarding the factors that affect academic procrastination, Scent and Boes (2014) also suggested the factors that affect academic procrastination:

1. Internal Factor

Internal factors are factors contained within the individual that affect academic procrastination. These factors include physical conditions and psychological conditions in individuals: 
Fadhli, Sudirman \& Kılınçer | An Investigation into the Self-Handicapping Behaviors in Terms of Academic Procrastination

a. Physical Condition

Factors that influence academic procrastination are physical and individual health conditions such as fatigue. Someone who experiences fatigue will have a higher tendency to procrastinate than those who do not.

b. Psychological Condition

According to Scent and Boes (2014), individual personality traits also influence procrastination behavior, such as the nature of social abilities, reflected in self-regulation and level.

\section{External Factor}

External factors are factors outside the individual that affect procrastination. These factors include parental care and a conducive environment, namely a lenient or tolerant environment.

a. Parenting style

Regarding parenting styles, Zakeri et al. (2013) conducted a study and found that the level of authoritarian parenting carried out by fathers led to chronic procrastination behavior tendencies in female research subjects, while the level of authoritative parenting performed by fathers resulted in daughters who are not procrastinators. Mothers who tend to avoid procrastination produce daughters who tend towards avoidance procrastination.

b. Non-lenient environmental conditions

Academic procrastination is carried out more in a low-supervised environment than in a highly supervised environment (Uzun et al., 2020). The environment and location of the school also affect academic procrastination.

Arikunto (2006) stated that whether or not a hypothesis is true has nothing to do with whether or not the hypothesis is proven. Errors in concluding may be caused by sample errors. Calculation errors exist in other variables that change the relationship between the variables studied. There was no relationship between variables in this study because other factors influenced the relationship, which was not the focus of this study.

Schwinger and Stiensmeier-Pelster (2011) provided empirical evidence about differentiating behavioral self-handicapping from self-reported selfhandicapping because these two types show different patterns of results, which strengthens the two types of self-handicapping. The subject does not treat the handicapping as a substitute option, but both form different self-protection behaviors. Although self-handicapping can help individuals protect self-esteem and help maintain self-image, the two types of self-handicapping show different primary motives underlying their use (Kong, 2020). Since behavioral selfhandicapping reduces a person's chances of success and can quite make the attribution of performance ambiguous (ambiguous) for oneself and others, behavioral self-handicapping most likely primary role is to protect the 
individual's self-esteem. Meanwhile, self-reported self-handicapping is known to have little effect on performance, so that the main underlying motive is more to maintain self-image.

Based on the review done by Schwinger and Stiensmeier-Pelster (2011), the selfhandicapping variable could not predict the criteria for academic procrastination. As stated above, self-reported self-handicapping does not have much effect on performance and has more function to maintain self-image, while in this study, what was revealed was self-reported self-handicapping and academic procrastination, which are essentially individual performances.

Related to academic procrastination, several conditions that arise due to selfhandicapping and pessimism above are thought to affect academic procrastination in a person. A tendency to refuse or avoid situations, lack of concentration, passiveness and low self-esteem are conditions that can make a person reluctant to face and complete the tasks that are his obligations. Reluctance to this task will eventually lead to the tendency of academic procrastination, as stated by Solomon \& Rothblum (1984). Other conditions such as low self-esteem and unrealistic views in dealing with conditions that occur can create a fear of failure, and subsequently, this can lead to procrastination in a person.

From this theoretical basis, it appears that the effect of self-handicapping on individual academic procrastination must go through many conditions, which may also be important to include in the study as an intervening variable because these conditions are known to be closely related to academic procrastination. Conditions that can be influenced by self-handicapping and academic procrastination can be used as intervening variables if researchers are interested in this research topic, including motivation, self-esteem, and academic achievement. In this study, these conditions have not been included as research variables that must be disclosed separately.

\section{CONCLUSION}

The results indicated no significant relationship between self-handicapping and academic procrastination in UIN Imam Bonjol Padang students. Thus, the variables of self-handicapping and academic procrastination cannot be used as a predictive basis for the criteria for academic procrastination.

The research provides empirical evidence about the importance of differentiating behavioral self-handicapping from self-reported because these two types showed different patterns of results, strengthening that the subject does not treat the two types of self-handicapping as a choice and can replace each other. However, they form different behavior for self-protection because behavioral self-handicapping reduces a person's chances of success and can quite make attribution of performance ambiguous for oneself and others. 
Fadhli, Sudirman \& Kılınçer | An Investigation into the Self-Handicapping Behaviors in Terms of Academic Procrastination

\section{REFERENCES}

Afzal, S., \& Jami, H. (2018). Prevalence of academic procrastination and reasons for academic procrastination in University Students. Journal of Behavioural Sciences, 28(1), 51-69.

Arikunto, S. (2006). Prosedur penelitian; Suatu pendekatan praktik. Jakarta: Bumi Aksara.

Balkis, M. (2013). Academic procrastination, academic life satisfaction and academic achievement: The mediation role of rational beliefs about studying. Journal of Cognitive and Behavioral Psychotherapies, 13(1), 57-74.

Barutçu Yıldırım, F., \& Demir, A. (2020). Self-handicapping among university students: The role of procrastination, test anxiety, self-esteem, and selfcompassion. Psychological Reports, 123(3), 825-843. https:// doi.org/10.1177/0033294118825099

Berglas, S., \& Jones, E. E. (1978). Drug choice as a self-handicapping strategy in response to noncontingent success. Journal of Personality and Social Psychology, 36(4), 405-417. https://doi.org/10.1037/0022-3514.36.4.405

Uzun, B., LeBlanc, S., \& Ferrari, J. R. (2020). Relationship between Academic Procrastination and Self-Control: The Mediational Role of SelfEsteem. College Student Journal, 54(3), 309-316.

Karami, A., Khodarahimi, S., Ghazanfari, F., Mirdrikvand, F., \& Barigh, M. (2020). The prediction of distress tolerance based on the feeling of loneliness and self-handicapping in students. Personality and Individual Differences, 161. https://doi.org/10.1016/j.paid.2020.109994

Kathleen, E., \& Basaria, D. (2021). The relationship between perfectionism and academic procrastination in college students learning online due to the covid-19 pandemic. In International Conference on Economics, Business, Social, and Humanities (ICEBSH 2021). https:// doi.org/10.2991/assehr.k.210805.188

Khaidir, E., \& Suud, F. M. (2020). Islamic education in forming students' characters at as-shofa Islamic High School, Pekanbaru Riau. International Journal of Islamic Educational Psychology, 1(1), 50-63. https://doi.org/10.18196/ijiep.1105 
Fadhli, Sudirman \& Kılınçer | An Investigation into the Self-Handicapping Behaviors in Terms of Academic Procrastination

Kınık, Ö., \& Odacı, H. (2020). Effects of dysfunctional attitudes and depression on academic procrastination: does self-esteem have a mediating role?. British Journal of Guidance $\mathcal{E}$ Counselling, 48(5), 638-649. https:// doi.org/10.1080/03069885.2020.1780564

Korstange, R., Craig, M., \& Duncan, M. D. (2019). Understanding and addressing student procrastination in college. Learning Assistance Review, 24(1), 57-70.

Kong, C. L. A. (2020). Academic motivation as a mediator between contingent selfesteem and self-handicapping: A sample of Hong Kong university students. (Outstanding Academic Papers by Students (OAPS), City University of Hong Kong).

Küchler, A.-M., Albus, P., Ebert, D. D., \& Baumeister, H. (2019). Effectiveness of an internet-based intervention for procrastination in college students (StudiCare Procrastination): Study protocol of a randomized controlled trial. Internet Interventions, 17(1). https:/ / doi.org/10.1016/j.invent.2019.100245

Martin, J. R. (2018). School was our life: remembering progressive education. Indiana. USA: Indiana University Press.

Park, S. W., \& Brown, C. M. (2014). Different perceptions of self-handicapping across college and work contexts. Journal of Applied Social Psychology, 44(2), 124-132. https://doi.org/10.1111/jasp.12204

Pavot, W. (2007). The assessment of subjective well-being. New York: The Guilford Press.

Rouzi, K. S., Afifah, N., Hendrianto, C., \& Desmita, D. (2020). Establishing an islamic learning habituation through the prophets' parenting styles in the new normal era. International Journal of Islamic Educational Psychology, 1(2), 101-111. https:// doi.org/10.18196/ijiep.v1i2.9638

Sarirah, T., \& Chaq, S. A. (2019). Academic self-efficacy as a predictor toward decisional procrastination among college students preparing a thesis in Indonesia. Journal of Advanced Research in Social Sciences and Humanities, 4(1), 23-28. https:// dx.doi.org/10.26500/JARSSH-04-2019-0104

Scent, C. L., \& Boes, S. R. (2014). Acceptance and commitment training: A brief intervention to reduce procrastination among college students. Journal of $\begin{array}{llll}\text { College Student } & \text { Psychotherapy, 28(2), }\end{array}$ 
Fadhli, Sudirman \& Kılınçer | An Investigation into the Self-Handicapping Behaviors in Terms of Academic Procrastination

\section{https://doi.org/10.1080/87568225.2014.883887}

Schmidt, H. G., Baars, G. J., Hermus, P., Molen, H. T., Arnold, I. J., \& Smeets, G. (2021). Changes in examination practices reduce procrastination in university students. European Journal of Higher Education, 1-16. https:// doi.org/10.1080/21568235.2021.1875857

Schwinger, M., \& Stiensmeier-Pelster, J. (2011). Prevention of self-handicapping - The protective function of mastery goals. Learning and Individual Differences, 21(6), 699-709. https:// doi.org/10.1016/j.lindif.2011.09.004

Schwinger, M., Trautner, M., Pütz, N., Fabianek, S., Lemmer, G., Lauermann, F., \& Wirthwein, L. (2021). Why do students use strategies that hurt their chances of academic success? A meta-analysis of antecedents of academic self-handicapping. Journal of Educational Psychology, 1-21. https://doi.org/10.1037/edu0000706

Solomon, L. J., \& Rothblum, E. D. (1984). Academic procrastination: Frequency and cognitive-behavioral correlates. Journal of Counseling Psychology, 31(4), 503-509. http://dx.doi.org/10.1037/0022-0167.31.4.503

Sugiyono, S. (2013). Metode penelitian pendidikan pendekatan kuantitatif, kualitatif, dan RED. Bandung: Alfabeta.

Willetts, D. (2017). A university education. New York: Oxford University Press.

Zakeri, H., Esfahani, B. N., \& Razmjoee, M. (2013). Parenting styles and academic procrastination. Social and Behavioral Sciences, 84, 57-60. https://doi.org/10.1016/j.sbspro.2013.06.509 